\title{
Upregulation of multi drug resistance genes in doxorubicin resistant human acute myelogeneous leukemia cells and reversal of the resistance
}

\author{
Yusuf Baran, Bala Gür, Pelin Kaya, Ali Uğur Ural, Ferit Avcu \& Ufuk Gündüz
}

To cite this article: Yusuf Baran, Bala Gür, Pelin Kaya, Ali Uğur Ural, Ferit Avcu \& Ufuk Gündüz (2007) Upregulation of multi drug resistance genes in doxorubicin resistant human acute myelogeneous leukemia cells and reversal of the resistance, Hematology, 12:6, 511-517, DOI: $10.1080 / 10245330701562535$

To link to this article: http://dx.doi.org/10.1080/10245330701562535

Published online: 04 Sep 2013.

Submit your article to this journal $\sqsubset$

Џll Article views: 20

View related articles $₫$

Citing articles: 18 View citing articles 5 


\title{
Upregulation of multi drug resistance genes in doxorubicin resistant human acute myelogeneous leukemia cells and reversal of the resistance
}

\author{
YUSUF BARAN $^{1,2, \dagger}$, BALA GÜR ${ }^{1, \dagger}$, PELIN KAYA $^{1}$, ALI UĞUR URAL ${ }^{3}$, FERIT AVCU $^{3}, \&$ \\ UFUK GÜNDÜZ ${ }^{1}$
}

${ }^{1}$ Middle East Technical University, Department of Biological Sciences, 06531 Ankara, Turkey, ${ }^{2}$ Izmir Institute of Technology, Department of Molecular Biology and Genetics, 35430 Urla, Izmir, Turkey, and ${ }^{3}$ Gulhane Military Medical Academy, School of Medicine, Department of Hematology, Etlik, 06010 Ankara, Turkey

(Received 23 March 2007; accepted 15 fune 2007)

\begin{abstract}
The major problem in the treatment of acute myeloid leukemia (AML) patients results from multidrug resistance to administered anticancer agents. Drug resistance proteins, MDR1 and MRP1, which work as drug efflux pumps, can mediate the multidrug resistance of human leukemia cells. In this study, the mechanisms of resistance to doxorubicin-induced cell death in human HL60 AML cells were examined.

Continuous exposure of cells to step-wise increasing concentrations of doxorubicin resulted in the selection of HL60/DOX cells, which expressed about 10.7-fold resistance as compared to parental sensitive cells. The expression analyses of MRP1 and MDR1 drug efflux proteins in doxorubicin-sensitive and -resistant HL60 cells revealed that there was an upregulation of MRP1 gene in HL60/DOX cells as compared to parental sensitive cells. On the other hand, while there was no expression of MDR1 gene in parental cells, the expression of MDR1 gene was upregulated in HL60/DOX cells. HL60/DOX cells also showed cross-resistance to cytosine arabinoside (Ara-c). This resistance was reversed by a combination therapy of Ara-c and cyclosporine A. However, the expression levels of CD15 and CD16 surface markers were significantly decreased in HL60/DOX cells.
\end{abstract}

Keywords: Multidrug resistance, MDR1, MRP1, AML, Doxorubicin, Cytosine arabinoside

Abbreviations: $A B C, A T P$ binding cassette; $A M L$, acute myeloid leukaemia; MDR, multidrug resistance; MDR1, multidrug resistance gene 1; P-gp, P-glycoprotein; MRP1, multidrug resistance associated gene1; DOX, Doxorubicin; Ara-c, cytosine arabinoside; Cyc-A, cyclosporine A; HL60/DOX, Doxorubicin-resistant HL60 cells; (IC)50, concentration of any chemical that inhibit cell growth by 50\%; MTT, 3-(4, 5-dimethylthiazol-2-yl)-2-5-diphenyltetrazolium bromide; RT-PCR, reverse transcriptase-polymerase chain reaction

\section{Introduction}

Doxorubicin, an antibiotic acting on DNA [1], and cytosine arabinoside (Ara-c), a cytosine nucleotide analogue [2], are two important chemotherapeutic agents used for the treatment of acute myeloid leukemia (AML). Resistance to chemotherapeutic agents is an obstacle to the successful treatment of AML. Several mechanisms may be responsible for this phenomenon, including failure of the drug to reach and affect its intracellular target, efflux of the administered drug from the cells, the inhibition of drug uptake into the cells or failure of the cells to undergo apoptosis [3-5].

In leukemias, transporter proteins located in the plasma membrane are often attributed to multi drug resistance (MDR). Several transporters have been identified to have a role in cancer and acute leukemias during the last decades [6,7]. The ATP-binding cassette $(\mathrm{ABC})$ proteins represent the largest family of transmembrane proteins. These proteins bind ATP

Correspondence: Y. Baran, Izmir Institute of Technology, Department of Molecular Biology and Genetics, 35430 Urla, Izmir, Turkey. Tel: + 90232 7507527. E-mail: yusufbaran@iyte.edu.tr

†Yusuf Baran and Bala Gür contributed equally to this manuscript. 
and use the energy to conduct the transport of toxic chemicals across the cell membranes $[3,8]$.

Multidrug resistance protein (MRP1, $190 \mathrm{kDa}$ protein), located on the cell membrane and membranes of intracellular compartments [3], can transport a variety of chemicals across those membranes $[9,10]$. In MRP1 deleted cell lines greater sensitivity to the anthracyclines, vinca alkaloids and epipodophyllotoxins has been observed $[9,10]$. In addition to MRP1, a $170 \mathrm{kDa}$ plasma membrane glycoprotein, P-glycoprotein (P-gp), encoded by MDR1 gene functions as an energy-dependent efflux pump for chemotherapeutic drugs across the membranes [10-13]. In cancer cells, intracellular accumulation of drugs was decreased to sublethal levels by increased expression of MDR1 gene, resulting in drug resistance. Expression of P-gp is associated with resistance to several types of antineoplastic agents, mainly anthracyclines, vinca alkaloids and epipodophyllotoxins [14].

The effects of chemotherapeutic agents can be increased by inhibiting MRP1 and especially P-gp in multidrug resistant cells. There are several agents that can inhibit P-gp, including calcium channel blockers, calmodulin antagonists, surfactants [15] and especially cyclosporine A. Cyclosporine A is known to have activity as an inhibitor of both MRP-1 and P-gp [16-19].

In this study, the involvement of MDR1 and MRP1 genes in the mechanisms of resistance to doxorubicin and Ara-c in HL60 cells was examined. The data presented here showed that, treatment with stepwise increasing concentrations of doxorubicin results in increased expression of the drug transporter proteins in resistant sublines, but not in parental cells. Resistance to anticancer agents can be reversed by a combination therapy using cyclosporine A.

\section{Materials and methods}

\section{Cell line and culture conditions}

Human HL60 acute myeloid leukemia cells were kindly provided by MSKCC, NY, USA. HL60 cells were maintained in RPMI 1640 growth medium containing $10 \%$ fetal calf serum and $1 \%$ penicillinstreptomycin at $37^{\circ} \mathrm{C}$ in $5 \% \mathrm{CO}_{2}$.

\section{Selection of doxorubicin-resistant HL60 cells}

Cells maintained in liquid cultures were exposed to step-wise increasing concentrations of doxorubicin $(30,50,70,90,110$, and $220 \mathrm{nM})$, which was kindly provided by Gulhane Military Medical School, Department of Hematology, Turkey. Subpopulations of cells those were able to grow in the presence of $220 \mathrm{nM}$ doxorubicin, were then selected, and referred to as HL60/DOX cells. Then, the inhibitory concentration 50 (IC) 50 values of doxorubicin, which inhibited the growth of the cell population by $50 \%$, were determined, and compared to parental sensitive cells as described below.

Measurement of growth by 3-(4,5-dimethylthiazol-2-yl)2-5 diphenyltetrazolium-bromide (MTT)

The $\mathrm{IC}_{50}$ values of doxorubicin and/or Ara-c that inhibited cell growth by $50 \%$ were determined from cell survival plots obtained by MTT as described previously [20]. Briefly, cells $\left(1 \times 10^{5}\right.$ cells/well $)$ were plated into 96-well plates (Costar, Cambridge, MA, USA) containing $100 \mu \mathrm{l}$ of the growth medium in the absence or presence of increasing concentrations of drugs at $37^{\circ} \mathrm{C}$ in $5 \% \mathrm{CO}_{2}$ for $24 \mathrm{~h}$. They were then treated with $0.1 \mathrm{~N}$ acidic isopropanol to dissolve the dark blue crystals of formazan after incubation in the presence of $5 \mu \mathrm{l}$ of MTT $(5 \mathrm{mg} / \mathrm{ml})$ for $4 \mathrm{~h}$. Finally, the plates were read in an Elisa reader (Ependorf, Germany) at $570 \mathrm{~nm}$. After that, the $\mathrm{IC}_{50}$ values of the compound were determined from cell survival plots as described [21]. Triplicate wells were used for each treatment.

\section{Isolation of total RNA and RT-PCR}

Total RNA was isolated from $1 \times 10^{6} \mathrm{HL} 60$ and HL60/DOX cells using Trizol reagent (including guanidium thiocyanate, phenol and sodium citrate) as described by the manufacturer. Quantification of RNA was conducted by measuring the absorbance at $260 \mathrm{~nm}$ by UV spectrophotometer. About $5 \mu \mathrm{g}$ of total RNA was reverse transcribed using reverse transcriptase. After $1 \mathrm{~h}$ incubation at $42^{\circ} \mathrm{C}$, the reactions were stopped by $70^{\circ} \mathrm{C}$ heating for $10 \mathrm{~min}$. The resulting total cDNA was then used in PCR to measure the mRNA levels of MRP1, MDR1 and $\beta$-microglobulin. The mRNA levels of $\beta$ microglobulin were used as internal control [22]. The primer sequences and PCR conditions were as follows: MDR1-forward (5'-TACAGTGGAATTGGTGCTGGG-3'), MDR1-reverse (5'-CCCAGTGAAAAAATGTTGCCA-3'); MRP1-forward (5'-TGAAGGACTTCGTGTCAGCC-3') MRP1-reverse (5'-GTCCATGATGGTGTTGAGCC- $\left.3^{\prime}\right)$ and $\beta$-microglobulinforward (5'-CTTACTGAAGAATGGAGAGAGA-3'), $\beta$-microglobulin-reverse (5'-CTTACATGTTCTCTATCCCACTT-3') [23]. Using these primers, $2 \mu 1$ of the reverse transcriptase reaction was amplified for 35 cycles $\left(94^{\circ} \mathrm{C}, 30 \mathrm{~s} ; 55-62^{\circ} \mathrm{C}, 45 \mathrm{~s} ; 72^{\circ} \mathrm{C}, 1 \mathrm{~min}\right)$ using Taq DNA polymerase (Fermentas, USA), and their levels were normalized to that of $\beta$-microglobulin as described previously [24].

\section{Determination of differentiation markers}

The extent of monocytic differentiation induced in HL60 cells by doxorubicin was determined by monitoring of the CD15 and CD16 surface markers 
by flow cytometry. The cell viability was determined by acridine orange prior to analysis. To detect the expression of the surface markers, aliquots of $1 \times 10^{6}$ HL60 cells were harvested at various time points, centrifuged, and washed twice with $1 \times$ PBS. The cell pellet was resuspended in $100 \mu \mathrm{l}$ of PBS and $20 \mu \mathrm{l}$ of monoclonal antibodies specific for CD15 and CD16 (Becton Dickinson, Mountain View, CA, USA) were added, and the mixture was incubated in the dark at $2-8^{\circ} \mathrm{C}$ for $15-30 \mathrm{~min}$. The excess antibody was washed off with $1 \times$ PBS, and the pellet was resuspended in $500 \mu \mathrm{l}$ of $1 \times \mathrm{PBS}$. The cells were analyzed by FACScan flow cytometer (Becton Dickinson, Mountain View, CA, USA).

\section{Results \\ Long-term exposure to increasing concentrations of doxorubicin results in the development of resistance in HL60 cells}

To explore the mechanisms involved in the development of resistance to doxorubicin-induced apoptosis, human HL60 cells were exposed to step-wise increasing concentrations of the drug $(30-220 \mathrm{nM})$ for a period of 12 months, and the sub-clones that expressed resistance were selected. First, the degree of resistance was determined by measuring the $\mathrm{IC}_{50}$ values of doxorubicin at $24 \mathrm{~h}$ using MTT assay. As shown in Figures 1 and 2, HL60 cells that survived upon chronic exposure to $220 \mathrm{nM}$ doxorubicin, which were referred to as HL60/DOX expressed about 10.7 -fold resistance, as compared to their parental sensitive counterparts. The $\mathrm{IC}_{50}$ values of Doxorubicin were found to be 62 and $666 \mathrm{nM}$ for HL60 (Figure 1) and HL60/DOX (Figure 2) cells, respectively.

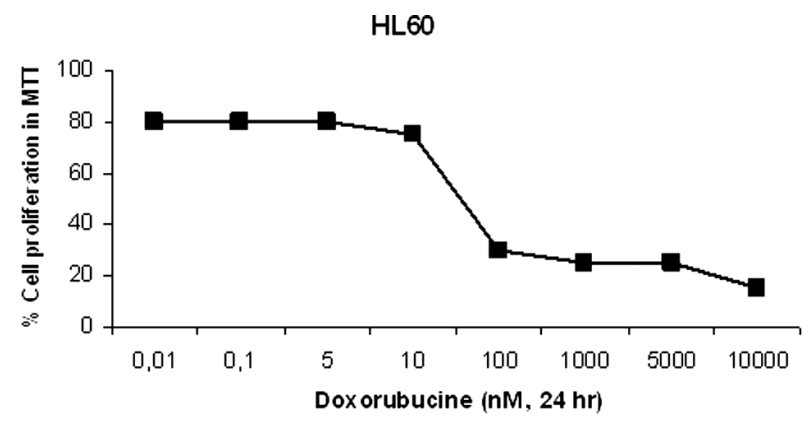

Figure 1. Effects of doxorubicin on the growth of HL60 cells, in situ. The $\mathrm{IC}_{50}$ concentration of doxorubicin was determined by MTT assay for HL60 cells as described. The MTT assays were performed using triplicate samples in at least two independent experiments. Statistical significance was determined using two-way ANOVA, and $p<0.001$ was considered significant.

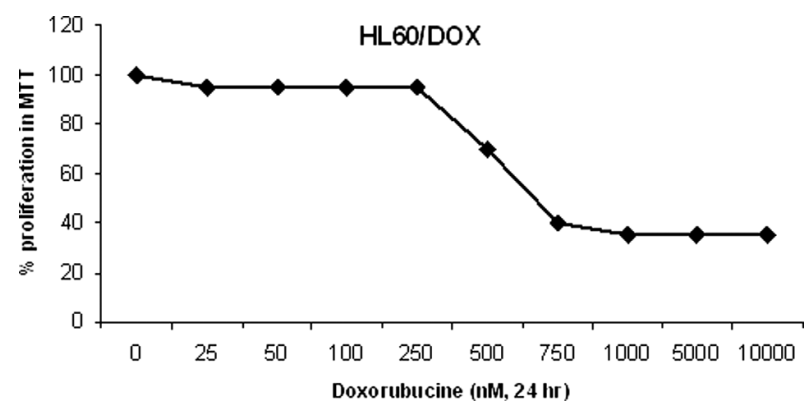

Figure 2. Effects of doxorubicin on the growth of HL60/DOX cells, in situ. The $\mathrm{IC}_{50}$ concentration of doxorubicin was determined by MTT assay for HL60/DOX cells as described. The MTT assays were performed using triplicate samples in at least two independent experiments. Statistical significance was determined using two-way ANOVA, and $p<0.001$ was considered significant.

Role of MRP1 and MDR1 in resistance to doxorubicininduced cell death

First, to examine whether mechanisms by which HL60/DOX cells express resistance to doxorubicininduced cell death involve the up-regulation of MRP1 and MDR1 gene expressions, the mRNA levels of MRP1 and MDR1 were examined by semi-quantitative RT-PCR.

In order to determine the expression levels of MRP1 both MRP1 and $\beta$-2-microglobulin primers were amplified in the same PCR mixture which gives an upper MRP1 (256 bp) and a lower $\beta$-2-microglobulin $(120 \mathrm{bp})$ bands. Figure 3 shows that there was a parallel increase in mRNA levels of MRP1 in Doxorubicin resistant HL60/DOX cells as compared to parental sensitive cells. Quantification analyses of MRP1 gene expression was conducted by using Vilber Lourmat Gel Imaging System, 3DI programme. The results showed that there was around 4.6-fold increase in expression of MRP1 gene in HL60/DOX cells as compared to parental cells (Figure 3).

Expression levels of MDR1 gene was also examined in both HL60/DOX and parental sensitive cells by RTPCR. Results revealed that there was no expression of MDR1 gene in HL60 cells. However, in HL60/DOX

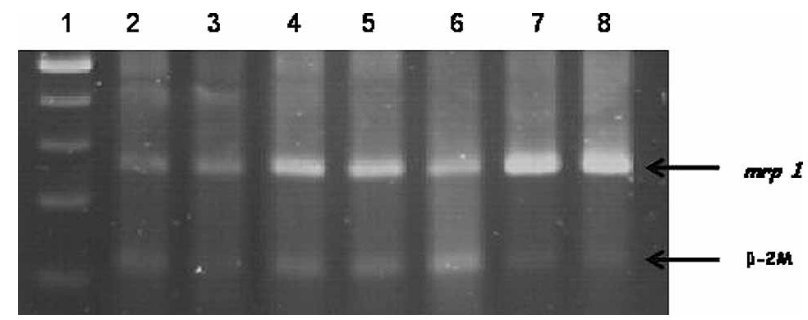

Figure 3. Expression analyses of MRP1 gene. Expression levels of MRP1 gene in parental and 30-, 50-, 70-, 90-, 110-, and $220 \mathrm{nM}$ doxorubicin resistant HL60 cells (lanes 2-8, respectively) were examined by RT-PCR. $\beta$-Microglobulin levels were used as controls (lanes $2-8$, respectively). Lane 1 is DNA ladder. 


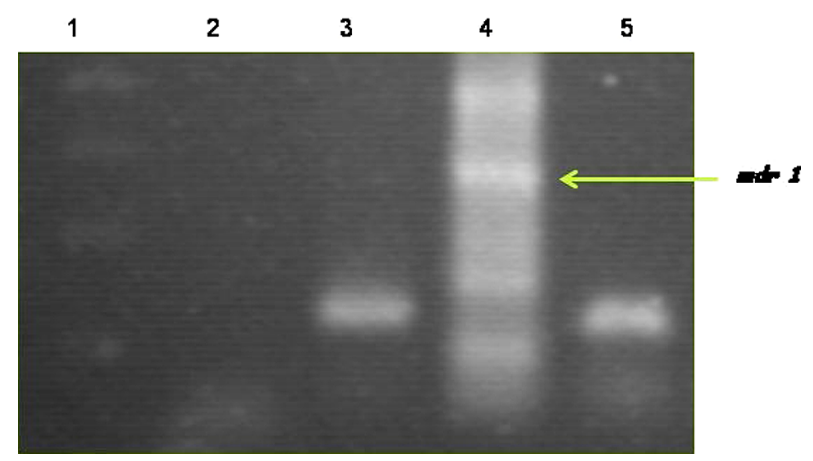

Figure 4. Expression analyses of MDR1 gene. Expression levels of MDR1 gene in parental and doxorubicin resistant HL60 cells (lanes 2 and 4, respectively) were examined by RT-PCR. $\beta$-Actin levels were used as controls (lanes 3 and 5 for HL60 and HL60/DOX, respectively). Lane 1 is DNA ladder.

cells, there was a significant expression of MDR1 gene (Figure 4). Taken together these results may suggest that HL60 cells can survive at higher concentrations of doxorubicin and this resistance can be explained by overexpression of the MRP1 and MDR1 genes.

\section{HL60/DOX cells showed cross-resistance to Ara-c}

Both parental and doxorubicin resistant cells were treated with increasing concentrations of Ara-c to examine any possible cross-resistance. MTT cell proliferation assay revealed that the $\mathrm{IC}_{50}$ values for Ara-c were 5.75 and $0.034 \mu \mathrm{M}$ for HL60/DOX and HL60 cells, respectively (Figure 5). There were around 39 and $76 \%$ cell viability in Ara-c treated HL60 and HL60/DOX cells which shows that HL60/DOX cell showed cross-resistance to Ara-c as compared to parental sensitive cells.

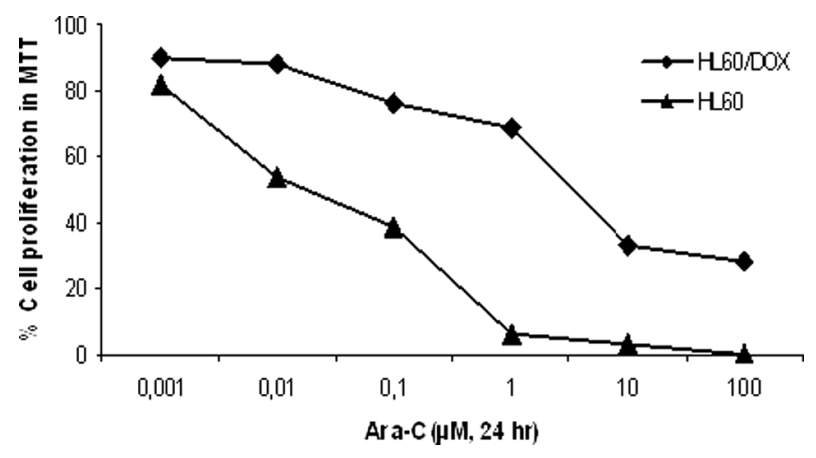

Figure 5. Effects of Ara-c on the growth of HL60 and HL60/DOX cells, in situ. The $\mathrm{IC}_{50}$ concentration of Ara-c was determined by MTT assay for both HL60 (triangle) and HL60/DOX (square) cells as described. The MTT assays were performed using triplicate samples in at least two independent experiments. Statistical significance was determined using two-way ANOVA, and $p<0.001$ was considered significant.

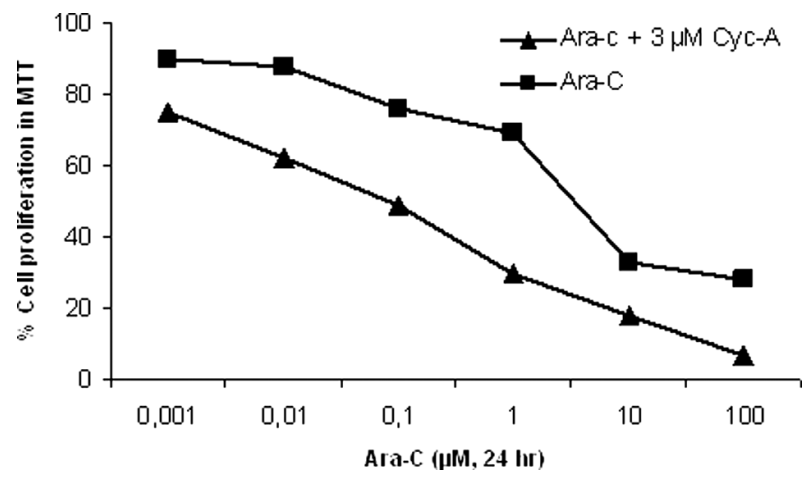

Figure 6. Effects of combination therapy of Ara-c and cyclosporine A $(3 \mu \mathrm{M})$ on the growth of HL60/DOX cells, in situ. The $\mathrm{IC}_{50}$ concentration of Ara-c (square) and combination therapy of Ara-c and $3 \mu \mathrm{M}$ Cyc-A (triangle) were determined by MTT assay for HL60/DOX cells as described. The MTT assays were performed using triplicate samples in at least two independent experiments. Statistical significance was determined using two-way ANOVA, and $p<0.001$ was considered significant.

\section{Inhibition of MRP1 and MDR1 by cyclosporine $A$ increases apoptotic effect of Ara-c in HL60/DOX cells}

The $\mathrm{IC}_{50}$ values of Ara-c and the combination therapy of cyclosporine-A $(3 \mu \mathrm{M})$ and Ara-c in HL60/DOX cells were examined. As shown in Figure 6, HL60/DOX cells, exposed to cyclosporine-A and Ara-c, expressed about 54-fold more sensitivity, as compared to only Ara-c applied counterparts. The $\mathrm{IC}_{50}$ values of Ara-c alone and cyclosporine-A in combination with Ara-c were 5.75 and $0.107 \mu \mathrm{M}$ for HL60/DOX cells, respectively (Figure 6). In $0.1 \mu \mathrm{M}$ Ara-c exposed HL60/DOX cells the cell proliferation was around $75 \%$, while it was $50 \%$ in $0.1 \mu \mathrm{M}$ Ara-c and $3 \mu \mathrm{M}$ cyclosporine A treated cells which indicate that resistance to anticancer agents in HL60 cells could be substantially reversed by cyclosporine A.

\section{Expression of the CD15 and CD16 markers on parental and doxorubicin-resistant HL60 cells}

To examine the variability of CD15 and CD16 expression in parental and doxorubicin resistant AML cells, flow cytometry was used (Figure 7). The results revealed that there were 82 and $81 \%$ expression of CD15 and CD16 markers in parental sensitive cells, respectively. However, the expression levels of CD15 and CD16 markers were decreased to 38 and $28 \%$ in doxorubicin resistant HL60/DOX cells (Figure 7).

\section{Discussion}

Multidrug resistance is the main problem in the treatment of human malignancies. In vitro studies are often useful for determination of the contributers to drug-resistance in human cancer cells. Generally, the genes and the proteins identified in these types of 

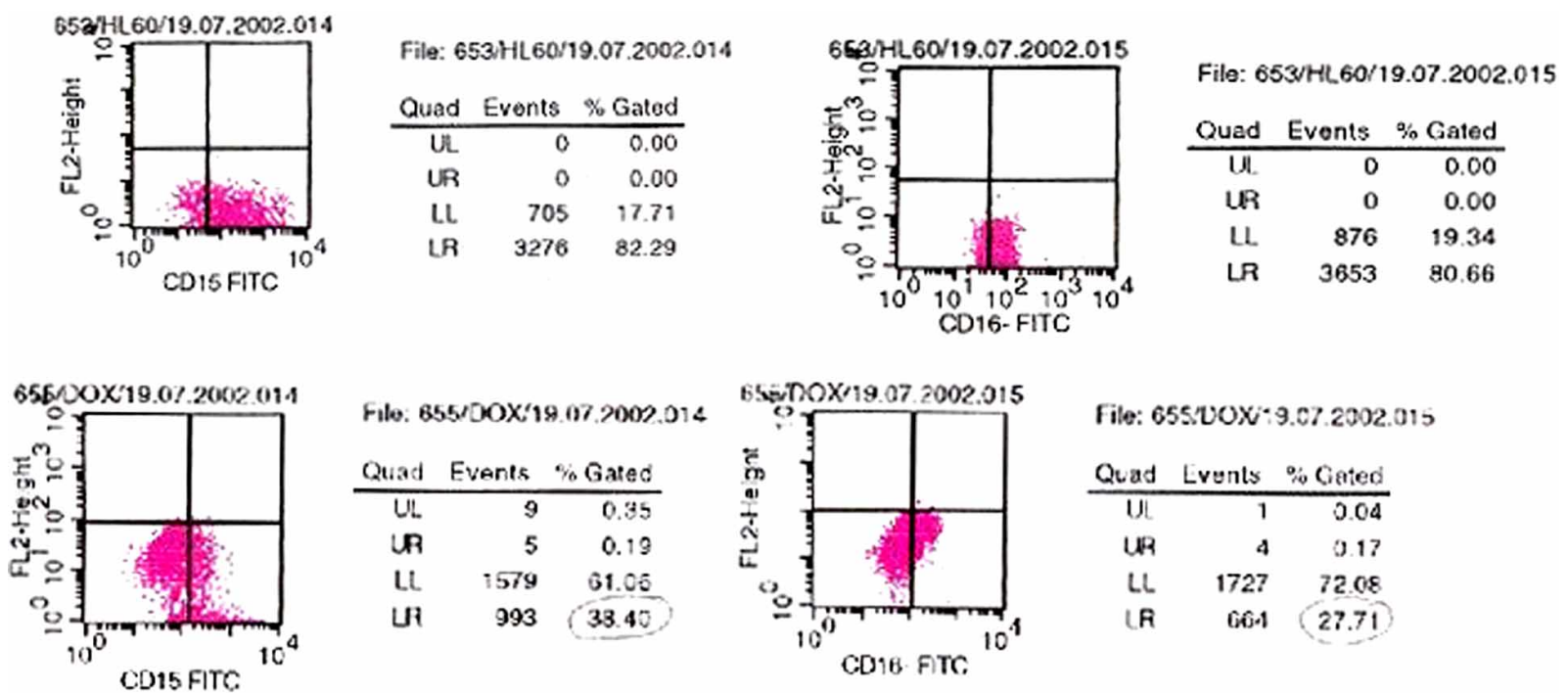

Figure 7. Expression analyses of CD15 and CD16 markers. Expression levels of CD15 and CD16 markers were examined by flow cytometry. Statistical analysis was done using one-way ANOVA, $p<0.001$ was considered significant.

in vitro experimental studies goes well with the in vivo data $[25,26]$ and the results of the clinical therapy [23]. Therefore, the application of experimental results is important for the discovery of new strategies for treatment of cancer and the prediction of the response created by cancer cells.

With this aim, HL60 cells were cultured in the presence of gradually increasing concentrations (up to $220 \mathrm{nM}$ ) of doxorubicin over a period of 12 months to generate doxorubicin-resistant sub-lines of human AML cells. The first observation from this study was difficulty in generating doxorubicin resistant HL60 cells which indicate the high efficiency of doxorubicin in the treatment of AML. Resistant cells were obtained by stepwise increasing concentrations of doxorubicin. The next highest drug concentration was applied to the cells when they could survive and proliferate at the present concentrations of doxorubicin. By that way HL60 cells could be grown up to $220 \mathrm{nM}$ doxorubicin and referred as HL60/DOX sub line. Similar approach has been used in various studies to derive drug-resistant cells starting with parental sensitive cells. HL60 cells resistant to vincristine $[27,28]$, to adriamycin [29] and to melphalan [30] were generated to investigate the resistance mechanisms and to reverse the MDR.

Cancer cells often display cross-resistance phenotype to structurally and functionally different anticancer agents that have never been applied. Cross-resistance to Ara-c in multidrug-resistant cells has been reported previously by different groups in vincristine resistant HL60 [27] and P388 cells [31] and in vincristine and doxorubicin resistant LBR cells [32]. In this study we also observed that doxorubicin resistant cells were also resistant to Ara-c. It has been well shown by Mansson and co-workers that Ara-C does also work as P-gp substrate in a P-gp-expressing promyelocytic leukemia subline.

Drug resistance resulting from overexpression of MRP1 or MDR1 were examined by RT-PCR analyses. The results have indicated that MRP1 gene expression was increased in parallel with increasing the levels of doxorubicin-resistance. On the other hand, while there was no expression of MDR1 gene in parental HL60 cells, doxorubicin application resulted in significant increase in expression of MDR1 gene. Hu and co-workers also showed upregulation of P-gp after $16 \mathrm{~h}$ application of epirubicin, daunorubicin, MX2 and Ara-c to blasts which were shown to be Pgp negative [33]. Upregulation of P-gp in vincristine resistant HL60 cells was reported by our group [27]. Weisburg and co-workers also showed that cells transfected with MDR1 gene containing vector were more resistant to complement-mediated cytotoxicity by antibodies against different cell-surface antigens [34]. Taken together the data suggest that, overexpression of MRP1 and MDR1 genes in HL60/DOX cells is at least partially responsible for doxorubicin and Ara-c resistance in human AML cells.

Therapeutic strategies aiming to overcome drug resistance is known as reversal of the resistance by using very specific inhibitors. In this study, inhibition of MRP1 and MDR1 may be useful in enhancement cytotoxic effects of Ara-c. In this setting, resistance to Ara-c can be reversed, at least in vitro, by variety of resistance reversal agents known as chemosensitizers. MDR modulators inhibit binding of transport proteins to anticancer agents resulting in accumulation of drugs in the cell. Apart from reversal modulators, the antisense oligomers targeted MDR1 
or MRP1 mRNA may also result in decrease and even loss of resistance, as there will be no transport protein synthesis. In this work cyclosporine $\mathrm{A}$ has been shown to have inhibitory effects on both transmembrane proteins. The MTT results showed that there was $76 \%$ cell viability in $0.1 \mu \mathrm{M}$ Ara-c applied HL60/DOX cells, while it was only around $49 \%$ in $0.1 \mu \mathrm{M}$ Ara-c and $3 \mu \mathrm{M}$ cyclosporine A applied cells. Thus, the sensitivity to Ara-c was increased as the cells exposed to the combination of drugs which indicates that MDR1 and MRP1 may somehow be responsible for Ara-c resistance.

In parallel with these results, MDR protein expression in malignancies; anticancer agent administration in combination with cyclosporine A generated encouraging results. Morgan and co-workers observed positive outcomes in combination therapy of carboplatin and cyclosporine A in resistant ovarian cancer [35], while Kruijtzer and co-workers obtained similar results with combination therapy of paclitaxel and cyclosporine $\mathrm{A}$ in advanced non-small-cell lung cancer [36].

CD15 and CD16 are expressed on adult granulocytes and are maintained throughout maturation [37]. CD15 and CD16 surface markers expression analyses revealed that there were a significant decreases in expression of CD15 and CD16 markers on HL60/DOX cells as compared to parental cells thus shows less maturity of resistant cells.

In summary, the multi-drug resistant HL60/DOX cell lines may represent a valuable model to identify drug resistance-associated genes. Further study, both in vitro and in vivo will hopefully establish the possible mechanisms of resistance in AML so that the prevention of the resistance by combination therapies will be more effective.

\section{Acknowledgements}

This study was supported by the research project by DPT-07-02-K120540-14 grant. We would like to thank Dr Bahar Baran for her help in preparation of the manuscript.

\section{References}

[1] DeVita VT, Hellman S, Rosenberg SA. Cancer: Principles \& practice of oncology. 7th ed. Philadelphia: Lippincott Williams \& Wilkins; 2005.

[2] Kolitz JE, George SL, Dodge JE. Dose escalation studies of Ara-C (A), daunorubicin (D) and etoposide (E) with and without multidrug resistance (MDR) modulation with PSC$833(\mathrm{P})$ in untreated adults with acute myeloid leukemia $(\mathrm{AML})<60$ years: Final induction results of CALGB 9621 . Blood 2001;98:461a, abstract.

[3] Gottesman MM, Fojo T, Bates SE. Multidrug resistance in cancer: Role of ATP-dependent transporters. Nat Rev Cancer 2002;2:48-58.

[4] Krishna R, Mayer LD. Multidrug resistance (MDR) in cancer. Mechanisms, reversal using modulators of MDR and the role of MDR modulators in influencing the pharmacokinetics of anticancer drugs. Eur J Pharm Sci 2000;11:265-283.

[5] Litman T, Druley TE, Stein WD, Bates SE. From MDR to MXR: New understanding of multidrug resistance systems, their properties and clinical significance. Cell Mol Life Sci 2001;58:931-959.

[6] Karp JE. MDR modulation in acute myelogenous leukemia: Is it dead? Leukemia 2001;15:666-667.

[7] Ross DD. Novel mechanisms of drug resistance in leukemia. Leukemia 2000;14:467-473.

[8] Borst P, Evers R, Kool M, Wijnholds J. A family of drug transporters: The multidrug resistance-associated proteins. J Nat Cancer Inst 2000;92(16):1295-1302.

[9] Doyle LA, Ross DD. Multidrug resistance mediated by the breast cancer resistance protein BCRP (ABCG2). Oncogene 2003;22:7340-7358.

[10] Leonard GD, Polgar O, Bates SE. ABC transporters and inhibitors: New targets, new agents. Curr Opin Investig Drugs 2002;3:1652-1659.

[11] Christina L, Linn H, Malin B, Kourosh L, Christer P, Staffan E. Mechanisms of cross-resistance between nucleoside analogues and vincristine or daunorubicin in leukemic cells. Biochem Biophys Res Commun 2004;320:825-832.

[12] Baker EK, Osta A El. The rise of DNA methylation and the importance of chromatin on multidrug resistance in cancer. Exp Cell Res 2003;290:177-194.

[13] Scotto KW. Transcriptional regulation of ABC drug transporters. Oncogene 2003;22:7496-7511.

[14] Dean M, Hamon Y, Chimini G. The human ATP-binding cassette (ABC) transporter superfamily. J Lipid Res 2001;42: 1007-1017.

[15] Ferry DR, Traunecker H, Kerr DJ. Clinical trials of Pglycoprotein reversal in solid tumours. Eur J Cancer 1996; 32A:1070-1081.

[16] List AF, Kopecky KJ, Willman CL, Head DR, Persons DL, Slovak ML, et al. Benefit of cyclosporine modulation of drug resistance in patients with poor-risk acute myeloid leukemia: A southwest oncology group study. Blood 2001;98:3212-3220.

[17] Twentyman PR, Versantvoort CH. Experimental modulation of MRP (multidrug resistance-associated protein)-mediated resistance. Eur J Cancer 1996;32A:1002-1009.

[18] Misbah Q, Kieran LO, Stacy MF, Nicole AW, William RG, Hans $M$, et al. Cyclosporin A is a broad-spectrum multidrug resistance modulator. Clin Cancer Res 2005;11:2320-2326.

[19] Hirrlinger J, Konig J, Keppler D, Lindenau J, Schulz JB, Dringen $\mathrm{R}$. The multidrug resistance protein MRP1 mediates the release of glutathione disulfide from rat astrocytes during oxidative stress. J Neurochem 2001;76(2):627-636.

[20] Baran Y, Gündüz U, Ural AU. Expression of MDR1 gene in HL60 cells selected with vincristine. Turk J Cancer 2005; 35(2):88-92.

[21] Piskin O, Ozcan MA, Ozsan GH, Ates H, Demirkan F, Alacacioğlu I, et al. Synergistic effect of imatinib mesylate and fludarabine combination on Philadelphia chromosomepositive chronic myeloid leukemia cell lines. Turk J Hematol 2007;24:23-27.

[22] Hirose M. Biology and modulation of multidrug resistance (MDR) in hematological malignancies. Int J Hematol 2002; 76:206-211.

[23] Filipits M, Suchomel RW, Dekan G, Haider K, Valdimarsson G, Depisch D, et al. MRP and MDR1 gene expression in primary breast carcinomas. Clin Cancer Res 1996;2(7): $1231-1237$

[24] Ogretmen B, Schady D, Usta J, Wood R, Kraveka JM, Luberto $\mathrm{C}$, et al. Role of ceramide in mediating the inhibition of telomerase activity in A549 human lung adenocarcinoma cells. J Biol Chem 2001;276:24901-24910.

[25] Chow KU, Nowak D, Kim SZ, Schneider B, Komor M, Boehrer S, et al. In vivo drug-response in patients with 
leukemic non-Hodgkin's lymphomas is associated with in vitro chemosensitivity and gene expression profiling. Pharmacol Res 2006;53:49-61.

[26] Gyorffy B, Serra V, Jurchott K, Abdul-Ghani R, Garber M, Stein U, et al. Prediction of doxorubicin sensitivity in breast tumors based on gene expression profiles of drug-resistant cell lines correlates with patient survival. Oncogene 2005;24: $7542-7551$.

[27] Baran Y, Gündüz Y, Ural AU. Cross-resistance to cytosine arabinoside in human acute myeloid leukemia cells selected for resistance to vincristine. Exp Oncol 2006;28(2):163-165.

[28] Dong BX, Chen XQ, Wang Z, Liang R, Bai QX, Huang GS, et al. Difference of gene expression profiles between HL60/VCR and HL-60 cells detected by human genome genechip. J Exp Hematol Chinese Association of Pathophysiology 2006;14(3):492-496.

[29] Demidenko ZN, Halicka D, Kunicki J, McCubrey JA, Darzynkiewicz Z, Blagosklonny MV. Selective killing of adriamycin-resistant (G2 checkpoint-deficient and MRP1expressing) cancer cells by docetaxel. Cancer Res 2005; 65(10):4401-4407.

[30] Pu QQ, Bezwoda WR. Induction of alkylator (melphalan) resistance in HL60 cells is accompanied by increased levels of topoisomerase II expression and function. Mol Pharm 1999; 56(1):147-153.

[31] Higashigawa $M$, Ido $M$, Kuwabara $H$, Hori $H$, Ohkubo $T$, Kawasaki H, et al. Membrane transport of $1-\beta$-D-arabinofur- anosylcytosine and accumulation of 1- $\beta$-D-arabinofuranosylcytosine 5'-triphosphate in P388 murine leukemic cells resistant to vincristine. Leuk Res 1991;15(4):255-262.

[32] Lopes EC, Scolnik M, Alvarez E, Hajos SE. Modulator activity of PSC 833 and cyclosporin-a in vincristine and doxorubicin-selected multidrug resistant murine leukemic cells. Leuk Res 2001;25(1):85-93.

[33] Hu XF, Slater A, Kantharidis P, Rischin D, Juneja S, Rossi R, et al. Altered multidrug resistance phenotype caused by anthracycline analogues and cytosine arabinoside in myeloid leukemia. Blood 1999;93:4086-4095.

[34] Weisburg JH, Curcio M, Caron PC, Raghu G, Mechetner EB, Roepe PD, et al. The multidrug resistance phenotype confers immunological resistance. J Exp Med 1996;183:2699-2704.

[35] Morgan RJ, Synold TW, Gandara D, Muggia F, Scudder S, Reed E, et al. Phase II trial of carboplatin and infusional cyclosporine in platinum-resistant recurrent ovarian cancer. Cancer Chemother Pharmacol 2004;54:283-289.

[36] Kruijtzer CM, Schellens JH, Mezger J, Scheulen ME, Keilholz $\mathrm{U}$, Beijnen JH, et al. Phase II and pharmacologic study of weekly oral paclitaxel plus cyclosporine in patients with advanced non-small-cell lung cancer. J Clin Oncol 2002;20: 4508-4516.

[37] Elghetany MT, Lacombe F. Physiologic variations in granulocytic surface antigen expression: Impact of age, gender, pregnancy, race, and stress. J Leukoc Biol 2004;75: 157-162. 